\title{
Early Sasanian landscape modification: New geoarchaeological evidence from the Ardashir Pond in southwest Iran (Palace of Ardashir, third century CE)
}

\author{
Morteza Djamali $^{1,2}$ (1) | Elnaz Rashidian ${ }^{1}$ | Alireza Askari-Chaverdi ${ }^{3}$ | \\ Cyril Aubert $^{1}$ | Elodie Brisset ${ }^{1}{ }^{\infty}$ | | François Demory ${ }^{4}$ | Nicolas Faucherre $^{5}$ | \\ Emmanuel Gandouin $^{1}$ | Hamid Lahijani ${ }^{2}$ | Nick Marriner ${ }^{6}$ | \\ Abdolmajid Naderi-Beni ${ }^{2}{ }^{\infty}$ | Andrew Parnell ${ }^{7}$
}

${ }^{1}$ Institut Méditerranéen de Biodiversité et d'Ecologie-IMBE (Aix Marseille Univ, Avignon Université, CNRS, IRD), Europôle de l'Arbois, Aix-en-Provence, France

${ }^{2}$ Iranian National Institute for Oceanography and Atmospheric Sciences (INIOAS),

Tehran, Iran

${ }^{3}$ History Department, Shiraz University, Shiraz, Iran

${ }^{4}$ Aix Marseille Univ, CNRS, IRD, INRAE, Coll France, CEREGE, Aix-en-Provence, France

${ }^{5}$ Laboratoire d'Archéologie Médiévale et Moderne en Méditerranée (LA3M), Aix Marseille University, CNRS, Aix-en-Provence, France

${ }^{6}$ CNRS, ThéMA UMR 6049, Université de Bourgogne Franche-Comté, Besançon Cedex, France

${ }^{7}$ Insight Centre for Data Analytics, Hamilton Institute, Maynooth University, Kildare, Ireland

\section{Correspondence}

Morteza Djamali, Institut Méditerranéen de Biodiversité et d'Ecologie-IMBE (Aix Marseille Univ, Avignon Université, CNRS, IRD), Europôle de l'Arbois, 13545 Aix-enProvence, France.

Email: morteza.djamali@imbe.fr

Scientific editing by Gary Huckleberry.

\section{Funding information}

Aix-Marseille Université; Centre National de la Recherche Scientifique; Agence Nationale de la Recherche

\begin{abstract}
The Sasanian period (224-651 CE) marked an era of large-scale urban projects in southwest Asia, including Iran's semi-arid highlands, with particular efforts to manipulate water bodies. This study presents a recent interdisciplinary investigation of a spring-fed pond at the entrance of the Palace of Ardashir (Firuzabad plain, southwest Iran), part of a recently registered World Heritage site. Historical accounts suggest that the entire water system of the plain, including the pond, underwent a hydraulic re-organization at the beginning of the Sasanian period, a fact that has never been investigated geoarchaeologically. A series of sediment cores were retrieved from the pond to probe its evolution and examine the extent of its landscape modification. The cores were sedimentologically described and radiocarbon-dated with age-depth models established based on 57 AMS (accelerator mass spectrometry) ${ }^{14} \mathrm{C}$ dates to understand the basin's depositional history. The results indicate that (i) Ardashir Pond has existed as part of a larger wetland complex since at least 4500 years ago, (ii) it was substantially enlarged at the beginning of the Sasanian era, and (iii) it was abandoned at the end of the Sasanian period. The Ardashir Pond is one of the first geoarchaeologically investigated case studies to demonstrate the Sasanian landscape in the framework of the "Iranshahr" sociopolitical concept.
\end{abstract}

\section{KEYWORDS}

Archaeology, human intervention, landscape, Late Antiquity, Sasanian architecture, water resource

This study is dedicated to Dietrich Huff for his tremendous contribution to our understanding of Sasanian archaeology in Iran. 


\section{1 | INTRODUCTION}

\subsection{Sasanian institutional landscape and water management}

Archaeological evidence and historical accounts attest to a period of widespread landscape modification in the Early Sasanian period (third century CE) in southwest Asia, mostly including urban foundations transforming the Fars region (Persis) in southwest Iran into an institutional landscape (Daryaee, 2009; Miri, 2009; Mittertrainer, 2020; Simpson, 2017). These urban places, with carefully drafted plans, were the core and basis of the Sasanian economy (Simpson, 2017, p. 43), and their landscape was shaped by dense settlements and optimal land use for the production of food supply and trade goods (Daryaee, 2009).

Management of water resources for large populations has always been a challenge on the semi-arid plains of the Iranian highlands. For this reason, the location and layout of such large-scale urban complexes were carefully chosen. A series of innovative plans and practices were implemented during the foundation of Early Sasanian urban centers (Huff, 1978; Simpson, 2017), along with architectural novelties and inventions for secular and religious buildings (Callieri, 2014). The optimal plan seems to have been large and densely populated urban centers in plains with a series of satellite villages and outposts, interconnected by a network of water management systems and routes. These include canals and qanats, which would transport water from the hills to the plains, as well as carefully integrated routes into the landscape with fire temples (Chartaqs) at a day-travel distance for resting and service.

Although Fars was the core of the Sasanian institutional landscape, neighboring areas in Khuzestan, Lorestan, Gorgan, and Damghan (Kumish) also saw significant urban projects, some new foundations and some expanded on earlier centers. The most prominent engineering project for water management is the Shushtar historical hydraulic system in Khuzestan (Figure 1), exploiting the largest river in Iran and providing an additional 40,000 ha of irrigated land for a dense population since Late Antiquity. This system consists of a diversion canal, redistributing water from the Karun River into a larger and a smaller waterchannel, which flow parallel to each other. The new and smaller channel had two purposes: (i) to irrigate the eastern plains of Khuzestan and (ii) to harness and control regional flood waters from the Zagros Mountains in numerous seasonal streams. The diversion system also provides the

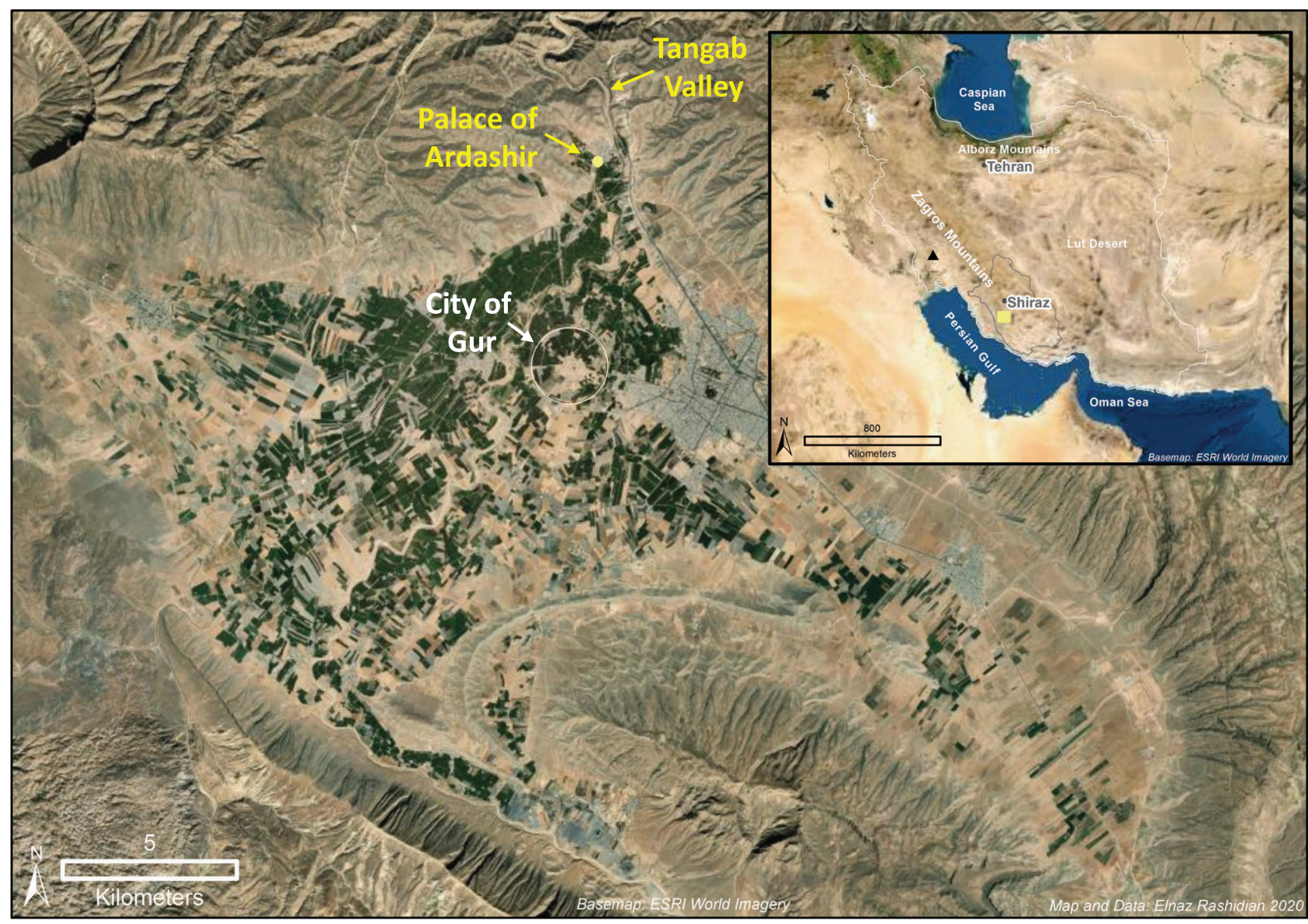

FIG URE 1 Geographical location of the Firuzabad Plain in SW Iran (the extent of the Fars province is outlined in gray, the extent of the imagery is denoted in yellow, and the location of the Shushtar hydraulic system is indicated by a black triangle) [Color figure can be viewed at wileyonlinelibrary.com] 

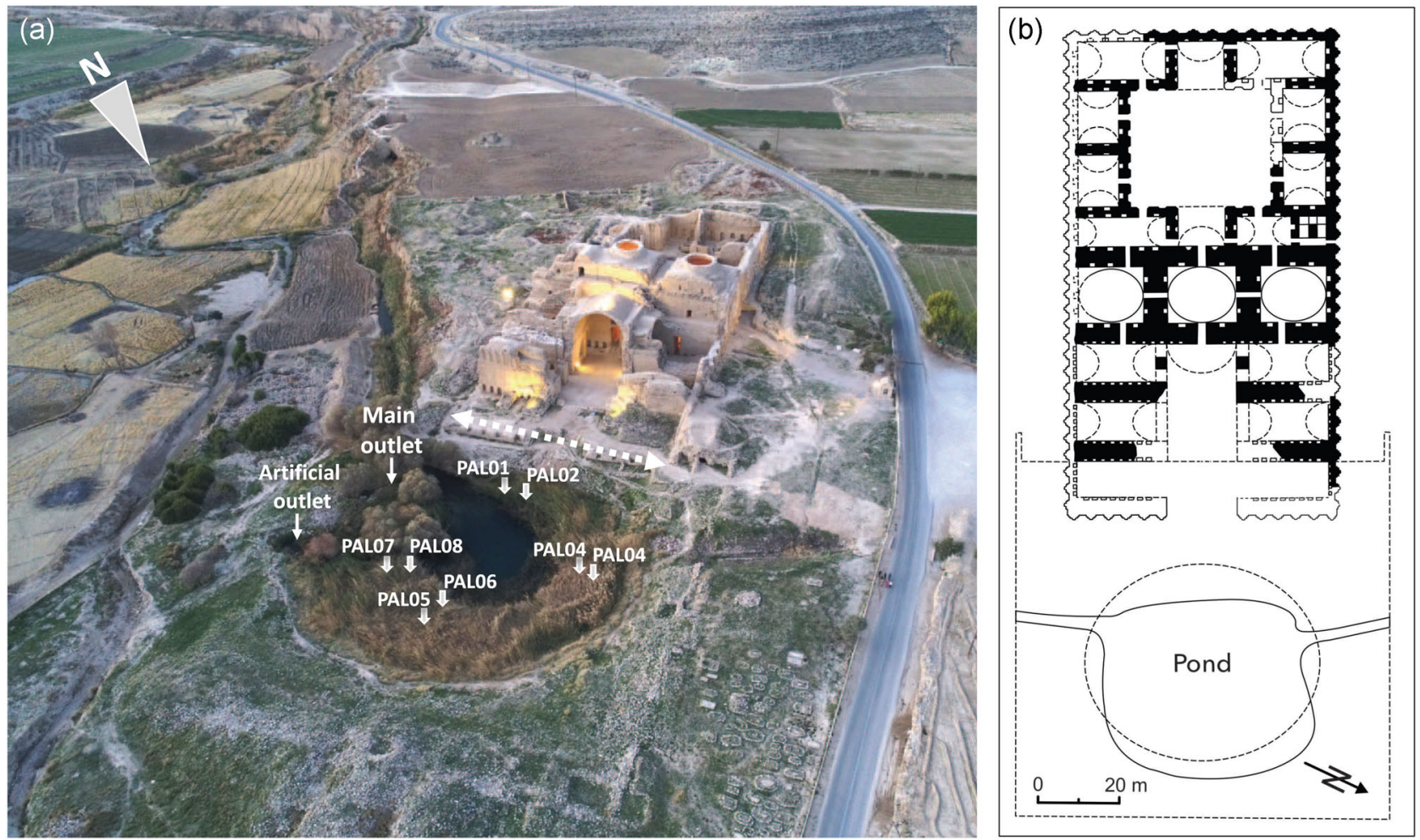

FIGURE 2 (a) Aerial photograph of the Palace of Ardashir and the Ardashir Pond (Autumn 2017). The frontal facade of the palace measures $56 \mathrm{~m}$ (dashed line) (photograph: courtesy of the World Heritage site of the Sasanian Archaeological Landscape of Fars). (b) Plan of the Palace and its pond modified after Hugi (1977) [Color figure can be viewed at wileyonlinelibrary.com]

watermills at the crossing of two channels with enough energy for working continuously. Such a multifunctionality of water management systems is typical of Sasanian urban planning. This UNESCO world heritage complex (reference no. 1315) was expanded in the Early Sasanian period based on an earlier structure with similar function. On smaller scales, there are aqueducts (Darabgird in Fars), spring-fed ponds with outlet canals (Gerdab Sangi in Khorramabad, Lorestan), and qanat series (Estakhr and Firuzabad in Fars) providing water to Sasanian urban areas.

This summary indicates the rich tradition of manipulated water bodies in the framework of the Sasanian institutional landscape. Until now, such invaluable examples of landscape reshaping have never been subjected to geoarchaeological and other interdisciplinary investigations. In the present study, we aim to fill this knowledge gap by providing insights into one of the most neglected water bodies, a spring-fed pond, at the entrance of one of the most emblematic Early Sasanian sites, the Palace of Ardashir in the Firuzabad, Fars (Figures 1 and 2).

\subsection{The Palace of Ardashir and its pond}

The foundation of the circular city of Ardashir Khurra ${ }^{1}$ on the Firuzabad plain in SW Iran (Figure 1) is mentioned as one of the heroic

${ }^{1}$ Ardašīr-Korra/Adashir Xawrrah (the divine glory of Ardashir). acts of Ardashir I, ${ }^{2}$ the founder of the Sasanian dynasty (Daryaee, 2010; Le Strange, 1905, p. 255; Mousavi \& Daryaee, 2012). Historical accounts such as Karnamak ${ }^{3}$ (Cereti, 2012; Mashkour, 1950) and Farsnama ${ }^{4}$ (Le Strange \& Nicholson, 1921) have documented the myths and oral history behind this act. The plain's hydraulic situation plays a crucial role in these stories (Afshar, 1961; Miri, 2009).

The Palace of Ardashir lies on the northwestern fringe of the plain, on an alluvial fan terrace (Figure 1). It is the second monumental building of the Sasanian tradition (after the first fortified monumental complex of Qale Dokhtar, ${ }^{5}$ a few kilometers to the north-east of the plain) and contains several architectural innovations (Huff, 2006, 2014). One of these innovations is the inclusion of the water element to create a specific landscape in the direct vicinity of the monument. Since then, this architectural element has become a signature of Iranian and Persianate monumental buildings (Canepa, 2018). Ardashir Pond, presented in this study, may be one of the first examples of a well-established architectural tradition in the Near East, which continues to reshape the landscape even today (Pope, 1965).

\footnotetext{
${ }^{2}$ Ardašir I Pāpakān.

${ }^{3}$ Kārnāmag ì Ardaxšěr ī Pābagān/Kār-nāmag (the book of deeds), a Late Sasanian manuscript (sixth century CE) in Middle-Persian Pahlavi dedicated to the story of Ardashir. ${ }^{4}$ Fārs-nāma of Ebn al-Balkị.

${ }^{5}$ Qal'a-ye Doktar.
} 

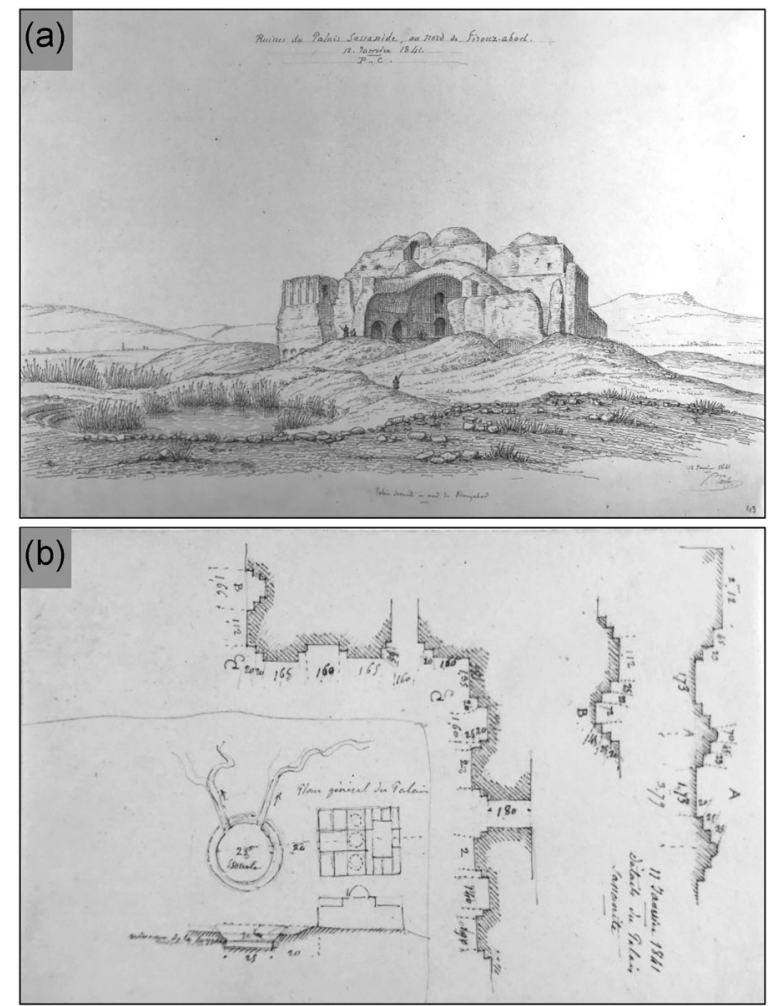

FIGURE 3 Pascal-Xavier Coste's drawings in 1841 documenting the rock circle structures in the lower-left corner of the pond (a) and the cross-section of the pond, which is $25 \mathrm{~m}$ in diameter (b)

The Palace of Ardashir (Figure 2) is part of a complex urban landscape established in the third century CE, marking the beginning of the Sasanian Empire (224-651 CE) ruling over four centuries in SW Asia (Daryaee, 2010; Huff, 2008; Wiesehöfer, 2001). According to the radiocarbon chronology, the Palace's construction dates back to the second half of the third century CE (Djamali et al., 2017). In 2018, this monument and several imposing rock reliefs, a fortified building complex, and a vast elegantly designed circular city (Figure 1) were registered in UNESCO World Heritage under the "Sassanid Archaeological Landscape of Fars" (reference no. 1568).

A significant architectural element of the Palace of Ardashir is a freshwater spring-fed pond (hereafter referred to as the "Ardashir Pond") located directly to the north of the monument and facing its majestic entrance (Figures 2 and 3). The semi-circular shape of the pond, as well as remains of rock circles in drawings by 19th-century European travelers (Figure 3a), suggest that the pond basin has been manipulated and reshaped most probably during the construction of the monument itself.

Ardashir Pond has an aerial extension of about $2500 \mathrm{~m}^{2}$. It is fed by a permanent freshwater karstic spring located in the northern part of the pond. The spring is most probably sourced in the karstic Oligo-Miocene limestone formation of Asmari, which outcrops along the Tangab Valley (Sedaghat et al., 2000). It is the most important permanent freshwater spring of the Firuzabad
Plain (Barzi, 1997). The pond basin bathymetry is funnel-like, with the deepest part corresponding to the resurgence point being more than $8 \mathrm{~m}$ below the pond's water level. Ardashir Pond is a hydrologically open system with a major outlet located to the south, feeding a permanent stream used to irrigate vast agricultural lands (Figure 2). This outlet seems to have been reshaped into a canal as part of the water management measures before the city's foundation (Huff, 2014).

Ardashir Pond also receives seasonal runoff from its environment (Figure 2a,b). The catchment area consists of the western and northwestern foothills of the pond. The general slope of the area is toward the southeast, where the water discharges through an artificial outlet channel. The main water input in the catchment area is gathered through a stream with a stable channel (Figure 2b), whose water volume varies seasonally. Other smaller streams (or shallow gullies) bring the surface water toward the pond in the wet season (winter) and diminish afterward. Although the pond is rather small in size (about $0.25 \mathrm{ha}$ ), its catchment area is significant (18 ha) due to its physical location at the foothills. The elevation difference between the highest point of the catchment area to the pond is $15 \mathrm{~m}$ and the distance is $500 \mathrm{~m}$ (see Novikmec et al. (2016), pp. 160-163 for a discussion on the relationship between pond size and catchment area size). The catchment area has been restricted in recent decades due to the physical growth of the village directly to the north of the pond and its successive landform modification.

\section{3 | Historical evidence for the reshaping of the Ardashir Pond}

There is strong historical evidence for large-scale hydraulic manipulation of the plain of Firuzabad before the foundation of the urban complex (Huff, 2014). As Istakhri reports (Afshar, 1961), the plain was not suitable for dwellings due to poor drainage, which created a water-logged landscape. After his victory over the last Arsacid (Parthian) king, Ardashir I (reigning from 224 to $240 \mathrm{CE}$ ) ordered the construction of a drainage network and built aqueducts providing his people with fertile arable land and a perfect circular city surrounded by satellite villages and gardens. Istakhri placed emphasis on the geometrical canals and the well-planned system of water management. In Karnamk, a narration about a pond is mentioned explicitly as being dug by him: "... He built the Ardashir Khawra Shahrestan (urban complex) there, in which he dug a large pond with four canals, where now Atashkadeh (fire temple) lies..." (Mashkour, 1950).

Ibn-Balkhi also mentioned that Ardashir built two ponds upon two springs (the older and the younger "Barm") in the Firuzabad plain during the city's foundation (Le Strange \& Nicholson, 1921, pp. 137-139), the former possibly corresponding to the pond investigated in this study and the latter probably indicating the archaeologically known cisterns in the inner circle of the city, near the monumental building of Takht-i Nishin (Huff, 1972). Although an unequivocal identification of Ardashir Pond with the one 
mentioned in the narrations is not possible, the crucial role of establishing ponds as an act of kings becomes clear from these examples. It further highlights the significance of hydraulic works associated with establishing the first Sasanian capital and the possible water management works in the plain, including ponds. ${ }^{6}$

Drawings by Pascal-Xavier Coste (Flandin \& Coste, 1851) suggest that the pond basin was larger in the mid-19th century than today due to pond sedimentation over the last two centuries (Figure 3). His precise drawings clearly show the presence of a rock circle structure surrounding a circular pond, suggesting that the pond basin was significantly enlarged and encircled by an anthropogenic structure made of stone blocks or bricks. This was confirmed by others in the mid-20th century (Huff, 1978).

The sketches show the existence of a second outlet and canal, trending in a southwest direction (Figure 3). Although the canal is no longer visible, the outlet's proximity to one of our coring sites (PAL07, Figure 2a) can still be seen in a structure that might have acted as a penstock. This canal might thus have functioned as a sluice for irrigation or other uses. A dense macrophytic vegetation belt composed mainly of Phragmites surrounds the pond nowadays (Figure 2a), which is regularly cut and used as fodder.

This brief description indicates an anthropogenic modification of this spring in the course of a large-scale urban project in the early third century CE. Understanding such hydraulic work and its effects on natural hydrological evolution of this freshwater ecosystem is crucial for several reasons. First, springs and spring wetlands have played a significant role in the socioeconomic and cultural evolution of societies in the arid to semi-arid lands of the Iranian plateau, not only as permanent freshwater sources but also as places of gathering for religious rituals (Boucharlat, 1979; Canepa, 2018; Djamali et al., 2018; Huff, 1972, 2014). Second, the pond is an inseparable architectural element in the Ardashir Palace complex and therefore an excellent case study to examine the extent and techniques of possible landscape modification by Sasanians. Third, the pond deposits associated with the modified spring can provide an invaluable sedimentary archive to reconstruct the environmental context of the establishment and evolution of the monument and the ancient city of Gur. Questions like the possible existence of Persian Gardens, dominant agricultural practices during the city's apogee, and hydroclimatic variations in the region can be addressed through paleoenvironmental investigations of such sedimentary archives.

To better understand this hydraulic construction and its cultural and environmental implications, we designed the current study to achieve the following objectives:

1. reconstruct the depositional history of Ardashir Pond;

${ }^{6}$ The large-scale water management of the Firuzabad Plain is under investigation as an interdisciplinary project "AQUA-IGNIS-The First City of the Last Empire." Preliminary results regarding the canalization and river manipulation, as well as underground waterharvesting techniques, will be presented in a series of papers in the near future.
2. establish a chronological framework for the natural changes versus anthropogenic interventions in the pond; and

3. present a case study for institutional landscape reshaping in the Sasanian period.

\section{2 | METHODS AND MATERIALS}

\subsection{Coring and sediment description}

Eight sediment cores were retrieved in October 2016 from the pond's littoral zone on the macrophytic vegetation belt (Figure 2a) using a Russian-type corer. These were collected and investigated to improve our understanding of the pond's history and to gain potential palaeoecological and geoarchaeological insights. Cores were then wrapped in film and placed inside half-cylinder PVC tubes and stored in $4^{\circ} \mathrm{C}$ cold rooms. All cores were then opened in a sedimentology laboratory and visually described based on physicochemical and biological characteristics to define nine sedimentary facies.

Detailed sedimentary logs and radiocarbon ages and age-depth models (Figures 4-6) were then established and used to (i) reconstruct the depositional history of the pond and (ii) detect significant anthropogenic interventions and management practices, particularly during the reign of the Sasanians. Sediment color was described using Munsell Soil Color Charts (Munsell Color Company, 2000). To reproduce the true Munsell colors in the sedimentary logs, Munsell to sRGB conversion tables were used (Centore, 2013).

Sediment cores were sampled using U-channels for magnetic measurements. We measured the U-channel with the recently developed high-resolution magnetic scanner (Demory et al., 2019) of the Rock Magnetic Laboratory of CEREGE (Aix-en-Provence, France). This scanner records the intensity of magnetic field variations at the sample surface that is produced by artificially induced isothermal remanent magnetization (IRM) acquired parallel to the bedding at $0.6 \mathrm{~T}$. This magnetization process can saturate low coercive ferromagnetic particles (e.g., magnetite) and partially mobilize high coercive ferromagnetic particles (e.g., hematite). This new technique reveals more subtle changes in the sediments' magnetic properties due to its high spatial resolution compared to magnetic susceptibility.

\subsection{Radiocarbon dating and age-depth modeling}

A total of 57 samples from seven cores (PAL02-PAL08; see Table 1 and Figure 2a) were radiocarbon-dated at Poznan Radiocarbon Laboratory. Core PAL01 was not ${ }^{14} \mathrm{C}$ dated because it is a sister core of PAL02 with almost the same stratigraphy. All radiocarbon ages were calibrated in OxCal 4.4 (Bronk Ramsey, 2009) using IntCal20 (Reimer et al., 2020) and are reported in Table 1. Most of the dated samples were composed of organic carbonate mud, organic mud, peat, and occasionally gastropod 


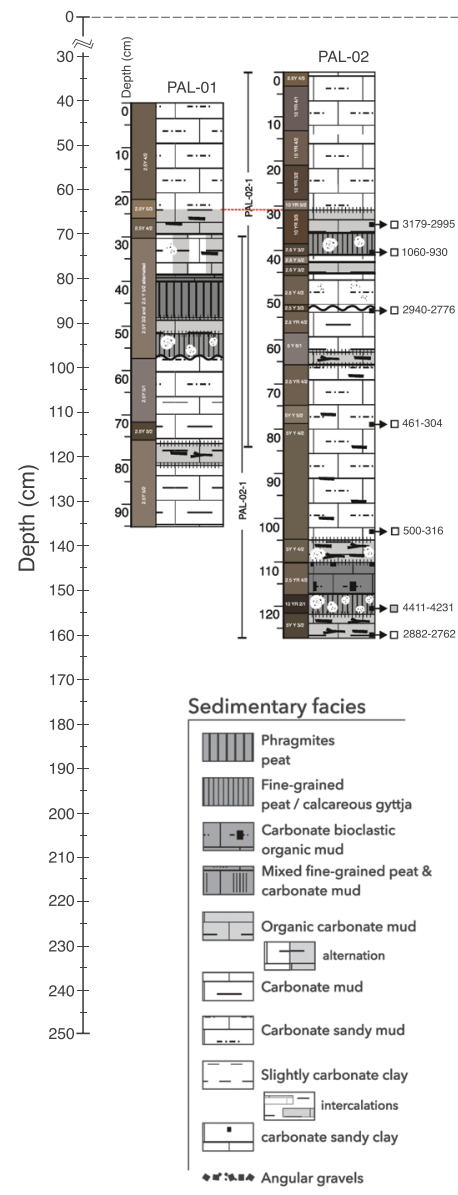

Water level
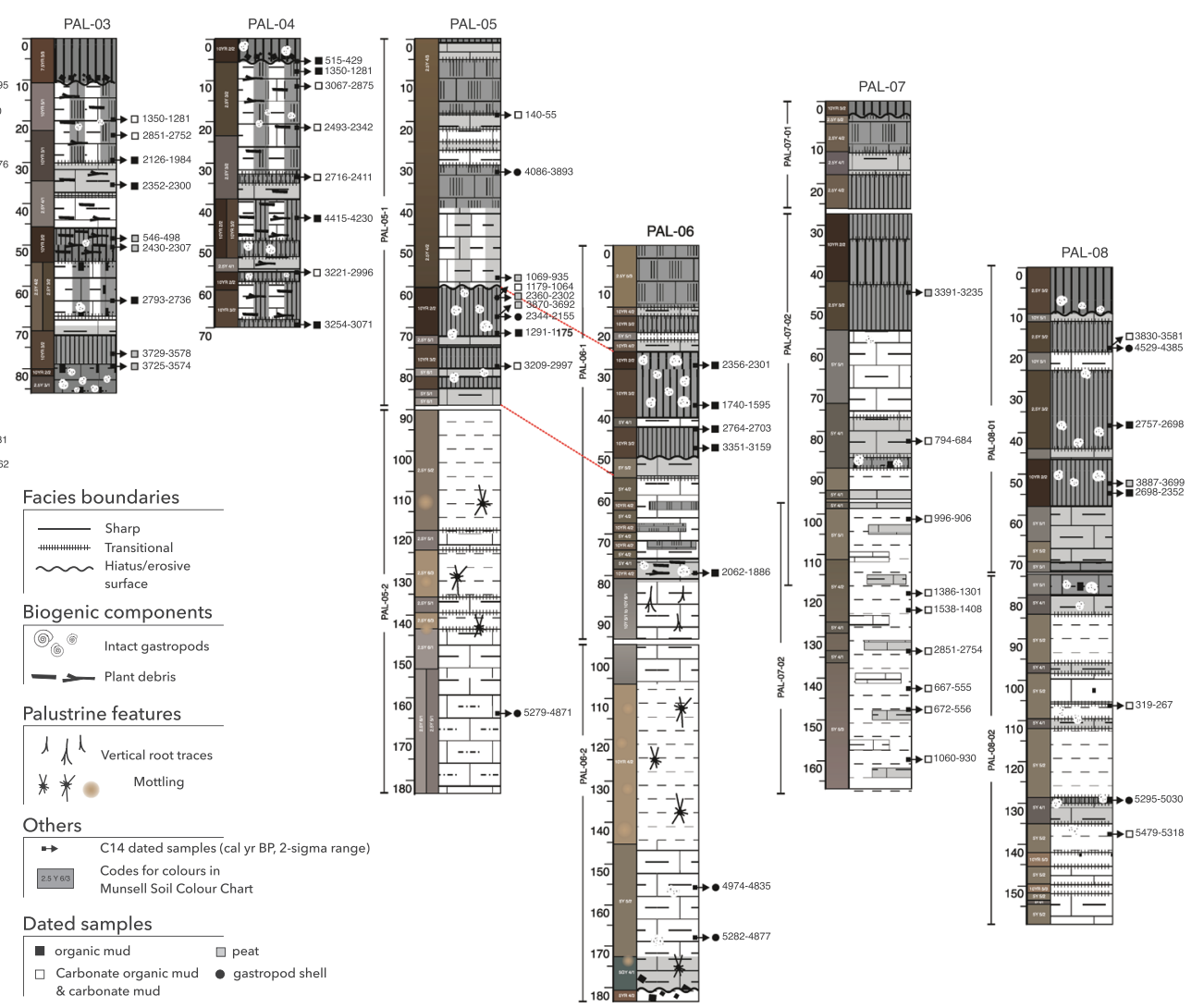

FIG URE 4 Detailed sedimentary logs of eight cores taken around the Ardashir Pond. The position of radiocarbon dates and the 2-sigma age ranges are also shown (cal year BP). The red dashed line corresponds to the visual correlation between adjacent (sister) cores based on the presence of the marker beds or the same lithological changes [Color figure can be viewed at wileyonlinelibrary.com]

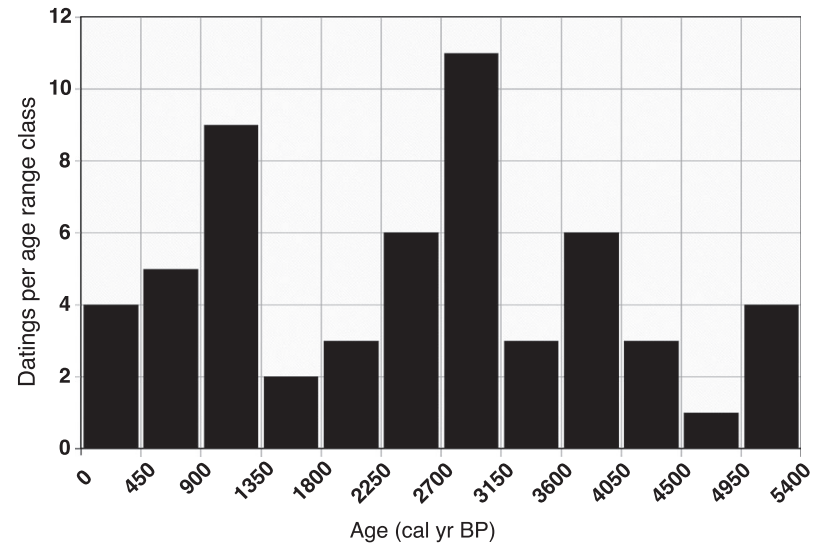

FIGURE 5 Age-range classes for 57 calibrated radiocarbon dates; see Table 1 for more details. Each class represents a 450-yearlong interval almost corresponding to the duration of the Parthian and Sasanian periods. The lowest numbers of dates have been obtained from the Sasanian period (1800-1350 CE) shells. Age-depth models were constructed based on a Bayesian approach in "Bchron" package (Haslett \& Parnell, 2008; Parnell et al., 2008). The code was run using $R$ version 3.5.3 (RStudio Team, 2015).

We used the "accumulation" output field in "Bchron" to create sedimentation rates for the eight sediment cores. In this study, the "sedimentation rate" is defined as the thickness of sediment accumulated during a given unit of time (cm/year), while "accumulation rate" is defined as the time needed for deposition of $1 \mathrm{~cm}$ of sediment (year $/ \mathrm{cm}$ ). The sedimentation rates were then used to construct spatial averages for the pond. All records were annualized using nearest-neighbor interpolation. These time series were subsequently summed and averaged (mean) to generate a spatially averaged late Holocene record of accumulation rates in years per centimeter (year/cm). To illustrate the general trends in the pond's sedimentation history, the data set was subsequently resampled at a 50-year resolution and used for Loess smoothing and bootstrap analysis. Loess smoothing is a generalization of moving average and polynomial regression, while the bootstrap analysis is a resampling method that uses 


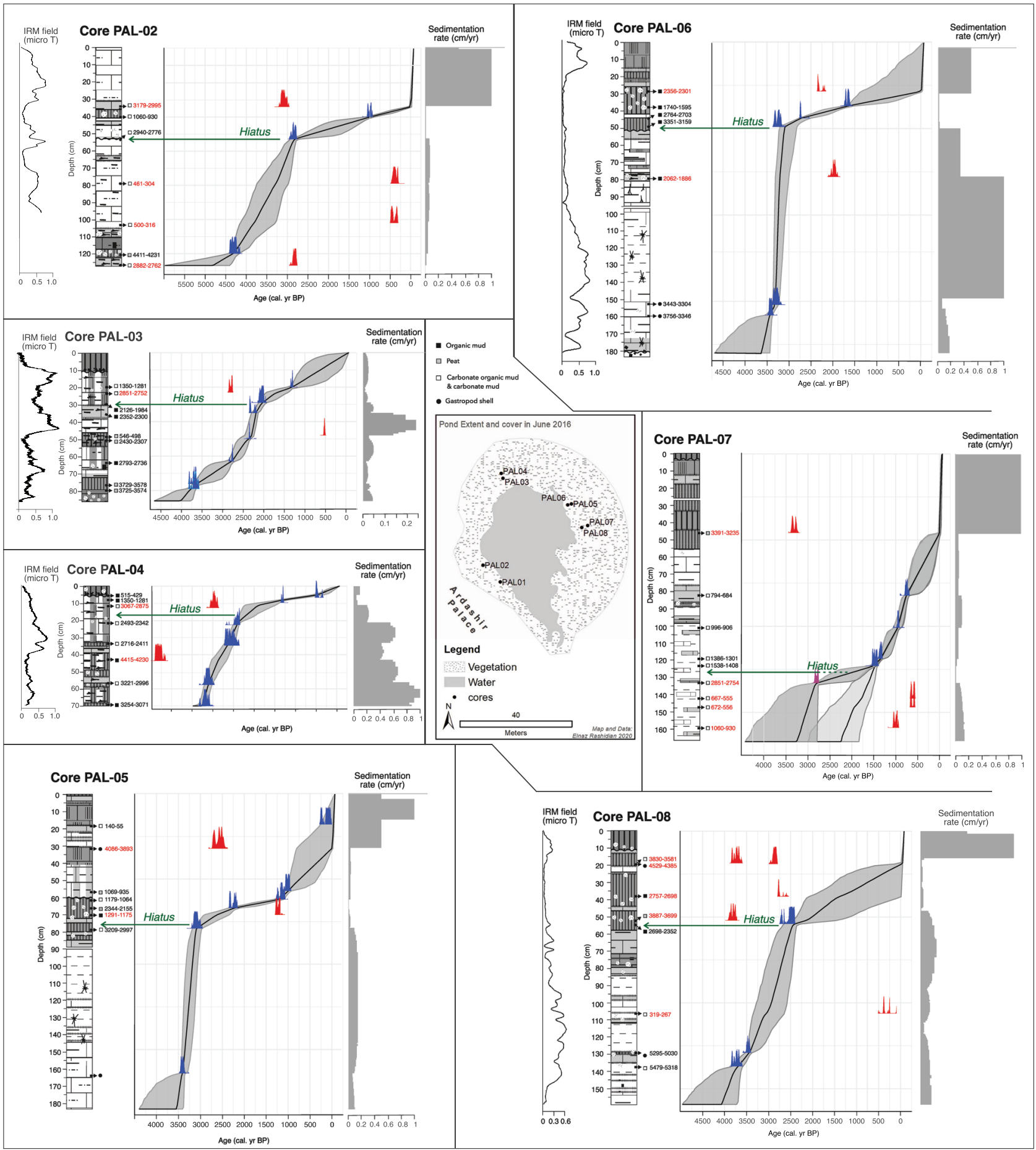

FIGURE 6 Bayesian models for sedimentation history of cores PAL02, PAL03, PAL04, PAL05, PAL06, PAL07 and PAL08 against sedimentary logs and induced remanent magnetic field (IRM). Locations of cores in Ardashir Pond are shown in the central panel. Sedimentation rates were extracted from the Bayesian age-depth models. A hiatus in sedimentation corresponding to ca. 1500 to 3000 cal year BP and including the Sasanian period is found in almost all sediment cores. The ages excluded by Bchron are marked in red. For PAL07, two models are presented, in which we retain the model marked in darker gray, where we re-incorporated the radiocarbon age at 133-134 cm depth [Color figure can be viewed at wileyonlinelibrary.com]

random sampling with replacement to mimic the sampling process (see Section 3.3). We also performed a short-time Fourier transform to highlight periods of significant statistical variability in the "accumulation" time series. 


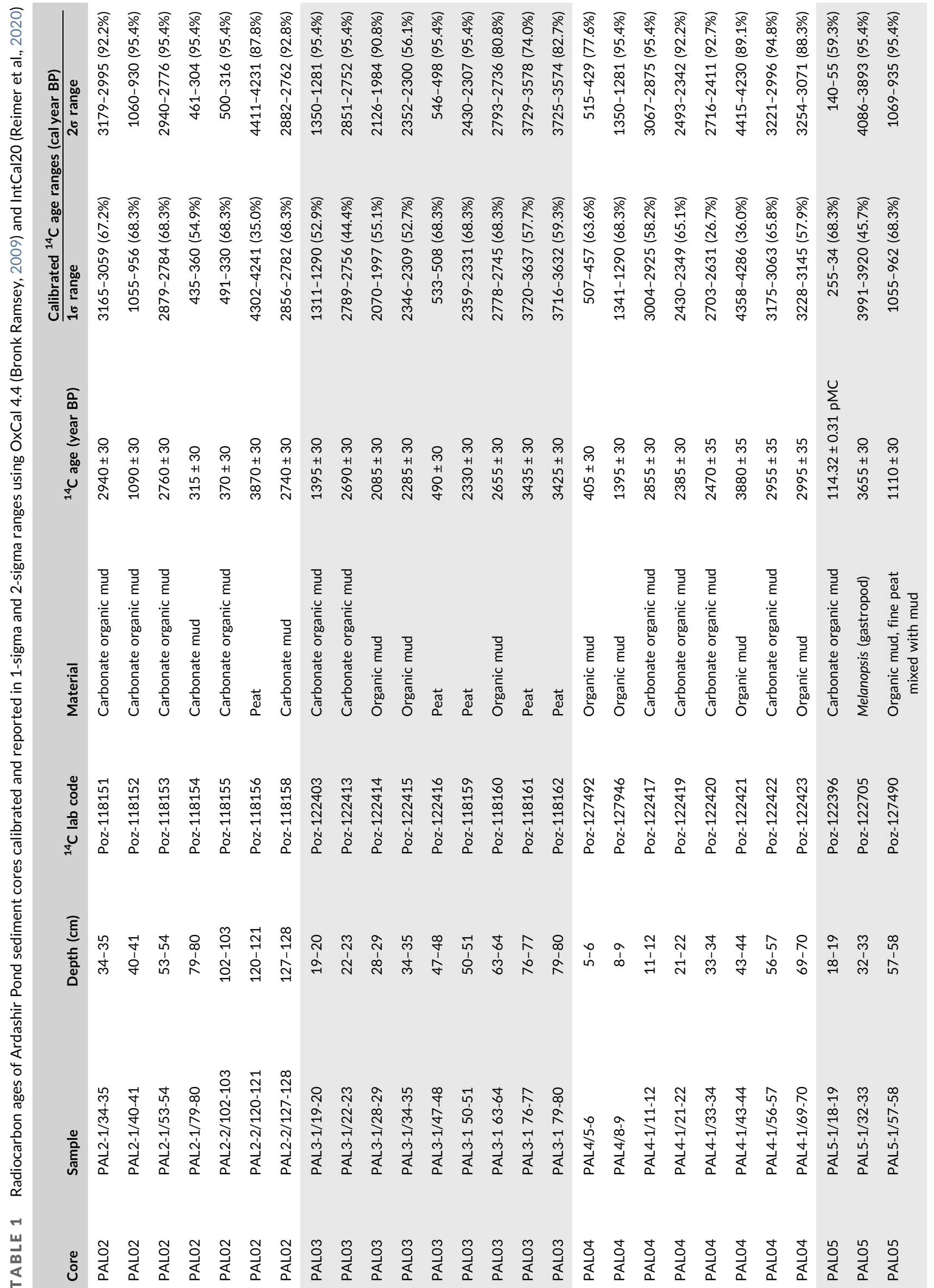



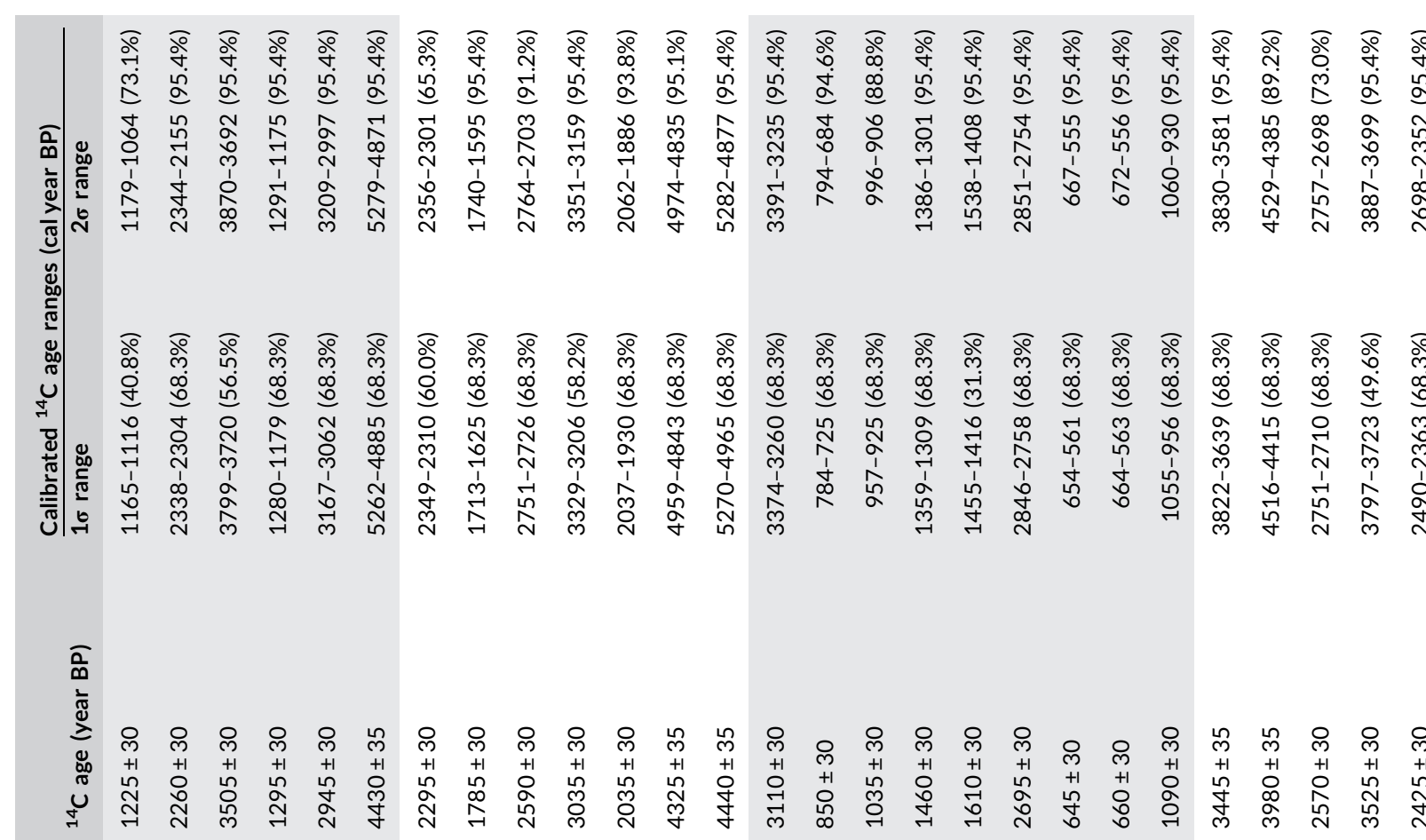

ஓ

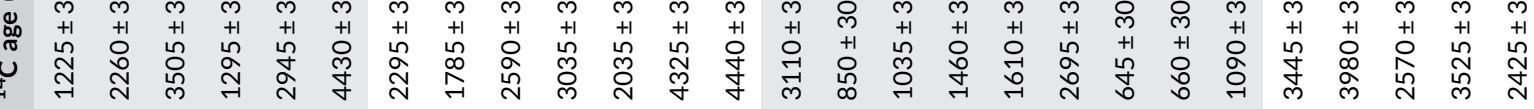

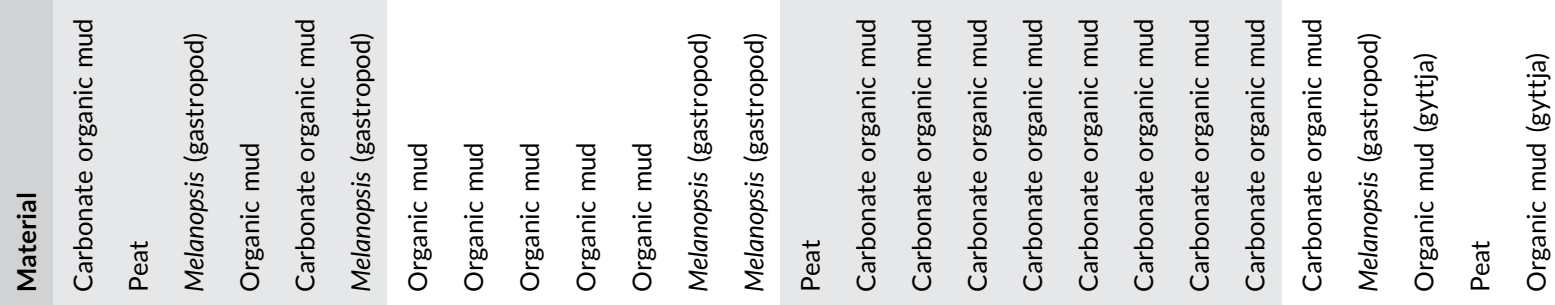

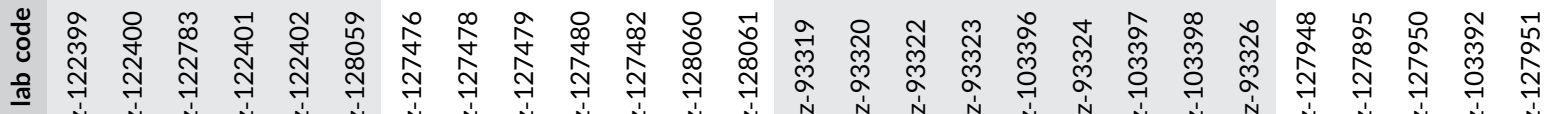

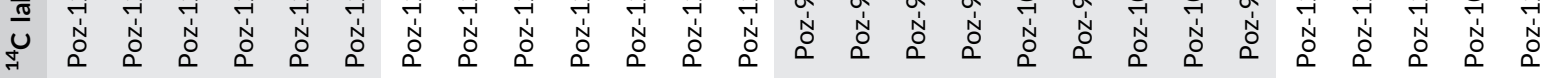

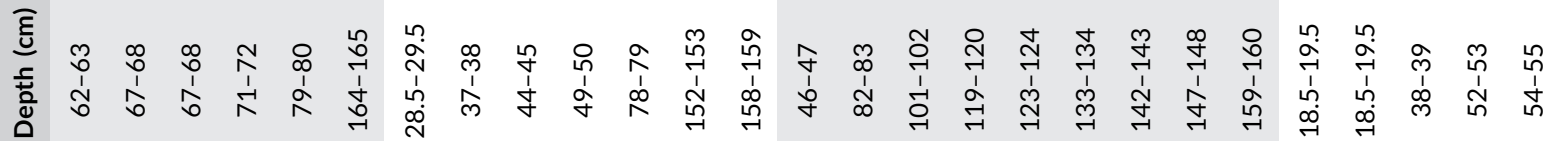

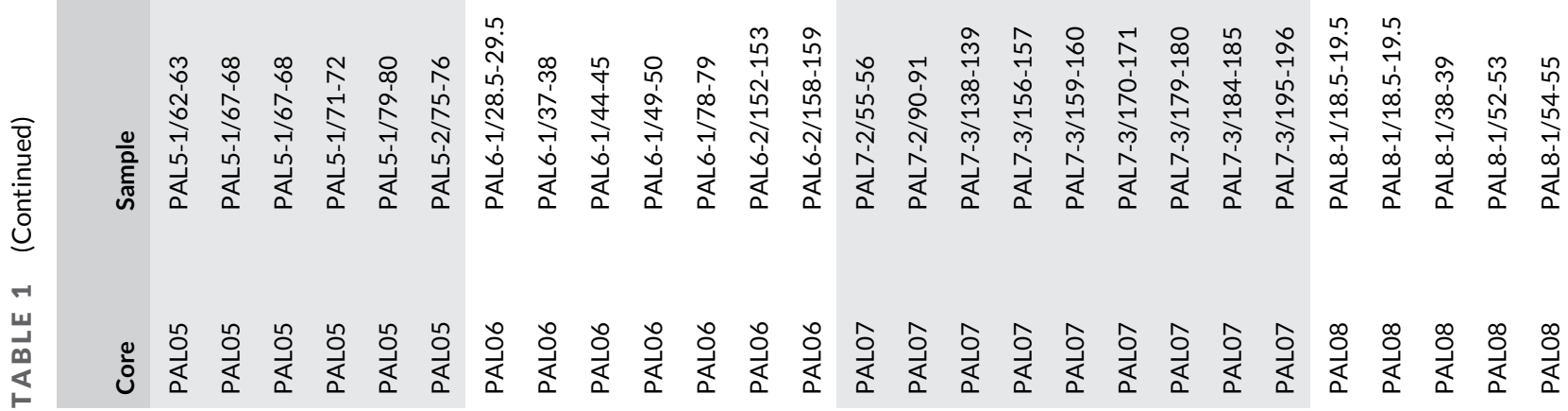




\section{3 | RESULTS AND INTERPRETATION}

\section{1 | Sedimentary facies}

Figure 4 shows detailed sedimentary logs from the eight cores of Ardashir Pond composed of nine sedimentary facies. These facies have been mainly deposited in two sedimentary environments: (i) a permanent lake/pond environment and (ii) a palustrine setting characterized by alternations of inundation/sedimentation and desiccation/pedogenesis.

\subsection{1 | Permanent lake/pond environment}

A variety of organic sedimentary facies dominate the upper parts of the cores. These facies, which contain abundant plant debris and intact gastropod shells, are characteristic of a vegetated low-energy shallow lacustrine/pond environment. The analogy with modern pond sediment suggests that the percentages of peat and plant debris decrease from the littoral macrophytic belt toward the central pond basin, where carbonate mud (lime) becomes the dominant sediment type. The carbonate mud is mostly chemically and biochemically precipitated from the spring waters saturated in bicarbonates (Ashjari \& Raeisi, 2006; Djamali et al., 2018). Thus, the following facies succession appears to represent a gradient from the littoral macrophytic vegetation belt to the deep lake/pond deposits close to the spring resurgence point: Phragmites peat, fine-grained peat/gyttja, carbonate bioclastic organic mud, organic carbonate mud, and carbonate mud.

\subsection{2 | Palustrine setting}

Lower sections of the longer cores (PAL05, PAL06, PAL07, PAL08) display fine-grained facies with some features that suggest deposition in a frequently inundated and desiccated marginal lake/pond environment with limited input of fine-grained detrital sediments. The dominant facies are a massive slightly carbonate mud with typical palustrine features, that is, "root traces" and "iron mottles" (Freytet \& Plaziat, 1982). The presence of these palustrine features shows that the depositional environment was alternatively inundated and desiccated, either seasonally or interannually (Alonso-Zarza, 2003).

Silt and clay with traces of sands are interpreted as episodes of seasonal runoff within the catchment basin. The presence of intercalations of carbonate mud suggests that the same area could also have been affected by sedimentation in a shallow marginal lake/pond or marsh environment. Both lacustrine and alluvial processes would thus have influenced the sedimentary environment. The resurgence point of Ardashir spring pond was not necessarily located in its current position and could have been farther from the modern pond. The development of terrestrial vegetation during the episodes of lower water tables on the mixed lake/pond and alluvial mudflat surfaces has left lots of root traces. However, no buried soil profile is observed as new flooding episodes impeded the pedogenic processes. Root traces and mottles are two 
sedimentary features indicating such alternative flooding-desiccation cycles in palustrine environments, which are common in semi-arid environments, including the Iranian highlands (Djamali et al., 2006, 2018). At the bottom of the core PAL06, a distinctive red-colored sediment was found, containing subangular gravels made of the limestone that indicates the lowest boundary of the palustrine-lacustrine deposit of Ardashir Pond at the coring site.

\subsection{3 | Anthropogenic deposits}

The pond's very anthropogenic context suggests that at least some parts of the material entering the pond are anthropogenic. Some sedimentary facies such as the carbonate sandy mud found in the top sediments of cores PAL01 and PALO2 are mainly of anthropogenic origin formed due to erosion and transportation of construction materials used in the palace (Figure 4). These materials include limestone blocks, plaster (gypsum), and mud bricks. The incorporation of these materials into natural carbonate mud and peat deposits at the coring sites of PAL01 and PAL02 is easily observed, where they are currently trapped and deposited within the dense reed vegetation belt (Figure 2).

The magnetic field intensity variations (see the left curves in Figure 6) provide a complementary proxy to characterize facies variations in the Ardashir Pond sediment cores. Magnetic fields vary from 0 to almost $1 \mathrm{mT}$, which correspond to magnetizations up to several $\mathrm{Am}^{-1}$ (Demory et al., 2019), showing a significant concentration of ferromagnetic particles in sediments. Organic facies of the examined cores display the lowest values in magnetic field record since they are mainly composed of dia- and para-magnetic particles, that is, particles with no magnetic remanence.

The lack of high values also shows the absence of ferromagnetic iron sulfides. However, exceptions are occasionally encountered in which some peat intervals display high magnetic field values, for example, in the topmost peat layers of PAL06 and PAL08. This is interpreted as incorporated ferromagnetic materials such as hematite derived from anthropogenic materials (e.g., bricks) into the peat fabrics. The highest magnetic field values also correspond to the palustrine muds in PALO6 and PALO8, most probably indicating the occurrence of magnetite (and/ or hematite) in the highly siliciclastic basal facies, consistent with the influence of detrital sediment input during alluvial processes. It is noted that the possibility of the contribution of atmospheric dust deposition to magnetic field variations is not excluded as the area has been exposed to significant dust input from Mesopotamia and Arabia and Eastern Africa since the mid-Holocene (Sharifi et al., 2015, 2018).

\section{2 | Chronological framework}

\subsection{1 | Radiocarbon dating: The problem of reservoir ages and age reversals}

The calibrated radiocarbon ages of the cores cover the last 5500 years. Figure 5 shows the distribution of the measured radiocarbon ages among different age-range classes (450-year intervals). The duration of the age classes was selected to approximately correspond to the Sasanian and Parthian empires (427 and 471 years, respectively). The lowest number of radiocarbon ages in upper core sections falls within the age-range class of 1800-1350 cal year BP, approximately corresponding to the Sasanian period (1726-1299 cal year BP/ 224-651 CE). This might be significant because the dated samples from the first sections of the cores are more frequent and more equally distributed. The low number of radiocarbon ages from the lowest core sections is due to fewer datable organic materials. The oldest radiocarbon ages were obtained from the shells of the freshwater snail Melanopsis sp. from the bottom of cores PAL05, PAL06, and PAL08. Melanopsis shells were the only available datable materials from the lower sections of PAL05 to PAL08 and their ages were important to extend our chronologies to the base of the cores. However, it is known that their shells present a reservoir effect that may vary from hundreds to several thousands of years (Lev et al., 2007). Lev et al. (2007) have radiocarbon-dated several living species of Melanopsis from different springs, streams, and lake environments associated with Lake Kinneret ("Sea of Galilee"), Israel, to estimate the reservoir ages of different water sources. Their study shows that the Melanopsis shells display a wide range of reservoir ages ranging from ca. 750 (Lake Kinneret) to ca. 7200 years (a spring directly flowing from an aquifer) and their ${ }^{14} \mathrm{C}$ content is in equilibrium with their habitat waters. They further estimate that the reservoir ages in Lake Kinneret have not varied significantly in time, allowing the use of obtained reservoir ages to correct the fossil Melanopsis radiocarbon dates.

To estimate the reservoir age of Ardashir Pond, we selected a layer in which we dated both Melanopsis shells and their encompassing fibrous Phragmites peat (Table 1; PAL05: 67-68 cm). The age offset after calibration was measured to be 1531 years based on the difference between the mid-points of 2-sigma calibrated ages. Assuming that the peat sample gives an age unaffected by the reservoir effect and that the water body's reservoir age has not significantly changed through time, we used the 1531-year offset to correct all radiocarbon ages obtained from Melanopsis shells. This correction was applied to radiocarbon ages before the construction of age-depth models.

Another problem encountered during the radiocarbon dating and calibration of samples was the unusually high number of age reversals (Figure 4 and Table 1). Although the Bayesian modeling helped to identify and exclude many of the outliers from the age-depth models (see the next section and Figure 6), the reason behind so many age reversals needs a more profound reflection. From the very beginning of the study, we had guessed that such a strongly human-impacted hydrosystem with a shallow littoral zone easily accessible to humans and their livestock could have, a priori, undergone intensive sediment disturbance and reworking. The studied sediment cores were all taken from this shallow peripheral zone of the pond, increasing the high possibility of the sediment to be disturbed by physical and biological processes.

The young ages incorporated within old sediment can be linked to the vertical penetration of root systems of both macrophytes and woody species. Another source for the age reversals 
could be the trampling of littoral sediments by livestock, especially cattle, horses, and donkeys. Animal legs can displace younger surface sediments to deeper depths. The older ages incorporated into the younger sediments may be related to reservoir effects (described above) and reworking and redeposition of old carbon by runoff from natural sediments (fossils, charcoals, plant remains) or weathering of anthropogenic materials, for example, liberation of plant remains from mud bricks. Furthermore, despite all the precautions taken, possible contamination during the coring operations cannot be excluded. Our choice of taking many cores and investing heavily in radiocarbon dating was an effort to minimize the errors and to maximize our chances of achieving a robust chronology for the whole site.

\subsection{2 | Age-depth models}

Bayesian age-depth models have been plotted against the sedimentary logs, induced remanent magnetic field values (IRM), and sedimentation rates for cores PAL02, PAL03, PAL04, PAL05, PAL06, and PAL08 (Figure 6). In total, 22 out of 57 radiocarbon ages were excluded by Bchron from the age-depth model reconstructions, of which 6 were too young but located in deep core sediments, and 11 were too old but located in top core sediments (Figure 6). In general, the age-depth models suggest the disturbed nature of the sediments of Ardashir Pond.
A common feature of all age-depth models is an abrupt change in the sedimentation rate occurring after 3000 cal year BP and before 1000 cal year BP (Figure 6). The changing rate is always negative, going from very high to very low sedimentation rates. For instance, in PALO2, the sedimentation rate of $>0.07 \mathrm{~cm} /$ year suddenly decreases to $<0.01 \mathrm{~cm} /$ year, consistent with a $10 \times$ decrease in the deposition rate. The inflection point in age-depth models shows a fundamental change in the sedimentation regime from an open environment with high inputs of exogenous sediments to a closed environment with the domination of endogenous sedimentation processes. The inflection point is also most probably indicative of a hiatus in sedimentation, at least in some of the sediment cores. In cores PAL02, PAL05, and PAL08, this hiatus is correlated with a sharp sedimentary boundary and lithofacies changes (Figure 6).

\section{3 | Depositional history}

Based on the comparison of age-depth models, sedimentary facies changes, and magnetic field variations, we propose a model for the depositional history of the Ardashir Pond (Figure 7). Figure 8 further shows an illustration of the statistical validity of the model. It clearly differentiates three proposed phases in the evolution of the pond and highlights the significant environmental changes (e.g., dredging) that occurred during the Sasanian period (see Figure 8 caption for more details).
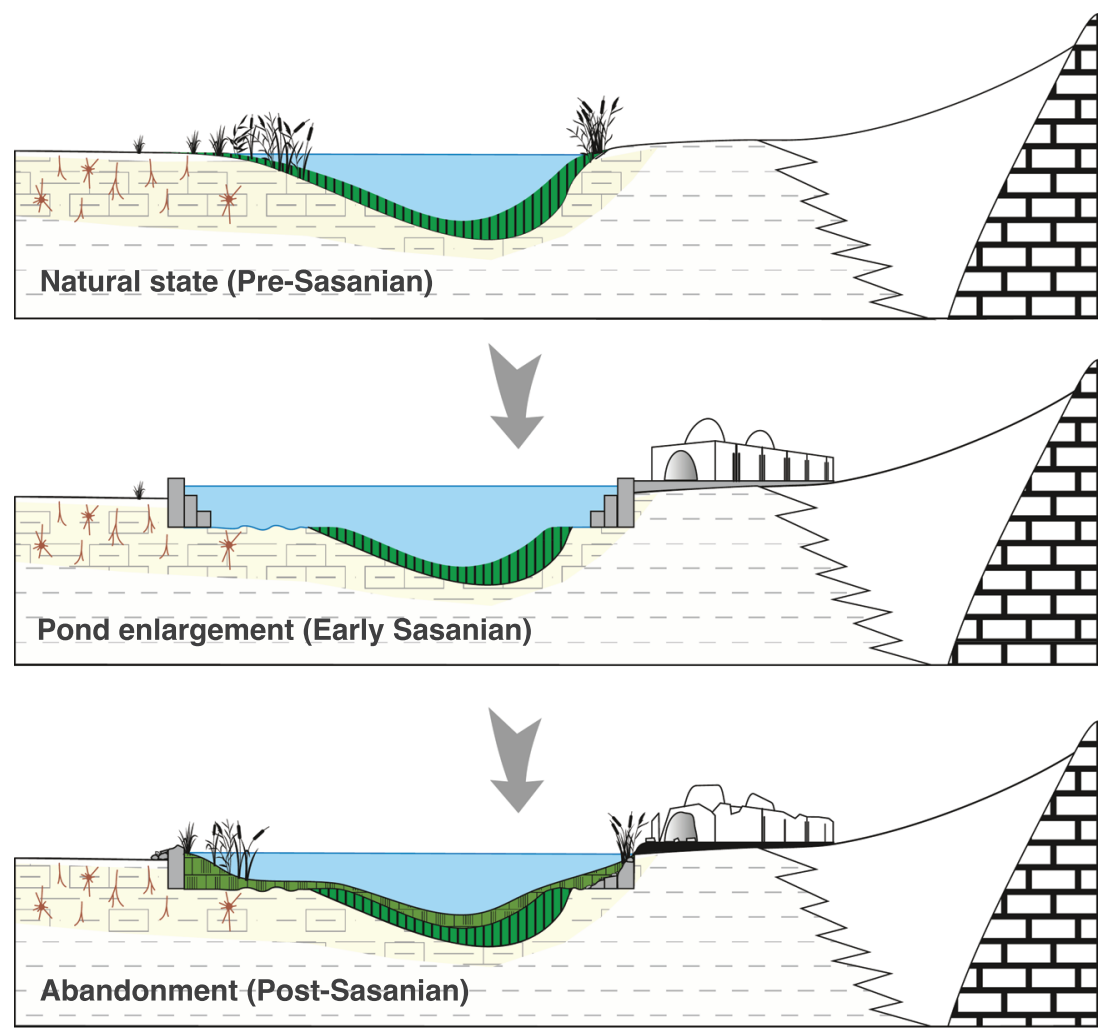

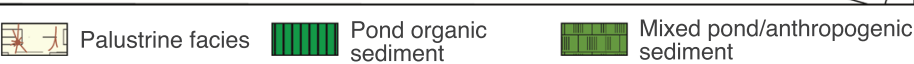

FIGURE 7 Schematic cross-section of the Ardashir Pond showing three stages in the pond's evolution deduced from the chronostratigraphic analysis of core sediments. Please note that this illustration is conceptual, and the vertical and horizontal scales are not proportional to the real dimensions. The cross-section roughly represents a NE-SW direction [Color figure can be viewed at wileyonlinelibrary.com] 


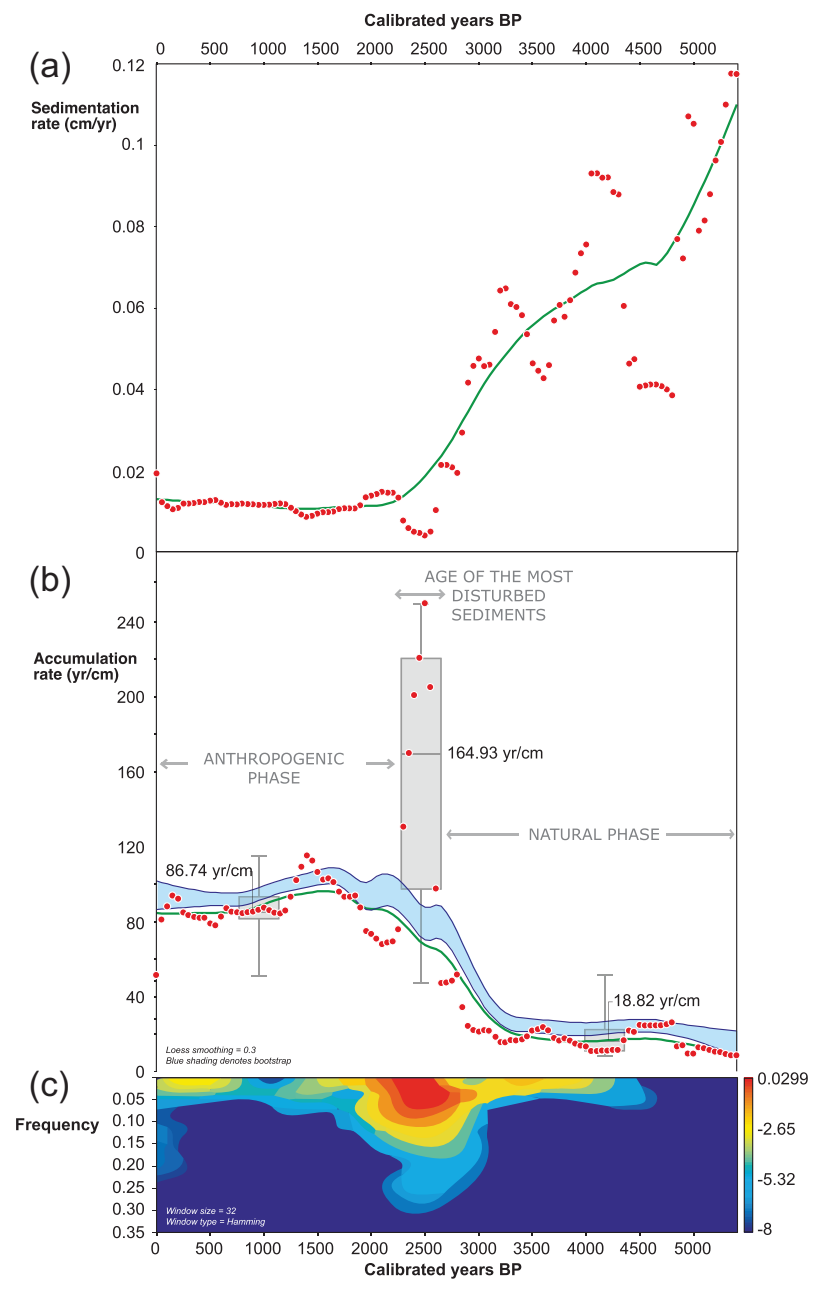

FIGURE 8 (a) Spatially averaged sedimentation rates in centimeters per year (cm/year) for Ardashir Pond, at 50-year intervals. The red dots denote the values. The green line shows the Loess smoothing (0.3). (b) Spatially averaged accumulation rates (shown in year/cm) for Ardashir Pond, at 50-year intervals. The red dots denote the values. The green line shows the Loess smoothing (0.3), and the blue lines and shaded area depict the bootstrap analysis. The boxplots correspond to the values present in each of the three intervals. (c) Short-time Fourier transform of the data ( window size $=32$, window type $=$ Hamming). All of the analyses clearly depict the transition from a natural to an artificial, humanmodified environment. The statistical analyses highlight the significant environmental changes (e.g., dredging) that occurred during the Sasanian modification of the pond [Color figure can be viewed at wileyonlinelibrary.com]

In general, three main phases can be inferred as follows.

\subsection{1 | Phase I: Palustrine-lacustrine system}

Before ca. 2500 cal year BP, there was a small lake/pond bordered by a seasonally waterlogged area at the present Ardashir Pond location. It received sediment and water from both the karstic carbonate spring and seasonal runoff from the surrounding slopes containing more ferromagnetic materials.
This environment was intermittently colonized by subaquatic and terrestrial vegetation. High magnetic field values show that ferromagnetic particles (magnetite and/or hematite) included in the siliciclastic fraction of alluvial origin largely contributed to the sedimentation. This shallow environment existed at least since ca. 4500 cal year BP as sediments were deposited on a stable topographic surface, attested by the presence of a poorly sorted red horizon most probably representing the alluvial fan surface in core PAL06 (Figure 4).

The deepest part of the Ardashir paleolake/pond was located closer to cores PAL03 and PAL04 as inferred from fewer facies variations observed in these cores (Figure 4). The latter cores' organic-dominated old sediments are contemporaneous with the minerogenic sediments of PAL05 to PAL08, suggesting the coexistence of a soil/sediment moisture gradient from more permanent water bodies into the more intermittently flooded and desiccated area. The highest average sedimentation rates in the pond's history are recorded during this pre-anthropogenic intervention phase (see the "Natural Phase" in Figure 8a,b).

\subsection{2 | Phase 2: Anthropogenic intervention in Ardashir Pond}

The occurrence of an abrupt change in the sedimentation rate preceding ca. 1500 cal year BP (Figure 6) indicates a significant anthropogenic intervention in Ardashir Pond. We interpret this change as evidence for (i) basin-wide dredging and removal of sediments (and vegetation) to enlarge the lake/pond basin and (ii) isolation of the Ardashir Pond catchment basin from the surrounding alluvial/ fluvial environments. The ages of sediments immediately below the inflection points on the age-depth models vary in different parts of the pond. They are approximately 1200 years younger in cores PAL03/PAL04 than PAL05/PAL06, suggesting that the thickness of the removed sediments was not constant everywhere in the lake/ pond basin (Figure 6). The dredging was mostly concentrated in the shallower parts of the wetland complex in the northeast.

Based on the Bayesian sedimentation models, the most likely age for the large-scale dredging and reshaping of the Ardashir Pond basin is at the beginning of the Sasanian period in the third century CE. This can be best deduced from the age-depth models of cores PAL03 and PAL04, which probably represent the pond's least disturbed sediments. Both cores display a change in the sedimentation rate and a possible dredging event occurring after 2000 cal year BP.

The time interval corresponding to the Sasanian period has provided the lowest number of radiocarbon dates during the last 3000 years (see the $1350-1800$ cal year BP corresponding to the 150-600 CE age-range class in Figure 5). This may be explained by the fact that after the construction of the Palace and reshaping of the pond, the catchment basin was restricted to the enclosure of the palatial complex, therefore receiving less exogenous input. Indeed, a careful inspection of the aerial photograph (Figure 2a) shows the ruins of the walls bordering the pond that would have acted as a 
barrier to sediment input. Past archaeological surveys have supported such a possible rectangular enclosure (Huff, 1972).

Furthermore, artificial dredging and maintenance of the pond hydrosystem cannot be excluded and may be supported by the lack or rarity of sediments corresponding to the Sasanian period (Figure 5). Dredging technology certainly existed at this time and is also widely attested in ancient harbors in the Mediterranean Sea from rapid silting, threatening the long-term viability of port basins (Marriner \& Morhange, 2006, 2007). Thus, sudden interruption in the allogenic sediment input substantially reduced the sedimentation rate and changed the nature of sediments. In almost all sediment cores, the post-Sasanian deposits became dominated by organic mud, gyttja, and peat, occasionally with intercalations of carbonate mud mostly precipitated through authigenic processes. The presence of some peaks in the magnetic logs, corresponding to these sediments, is related to the incorporation of anthropogenic ferromagnetic materials such as brick fragments into the pond sediments (e.g., PALO2 and PAL03, Figure 6).

As is shown in Figure 7, the anthropogenic intervention (Phase 2 ) in Ardashir Pond is characterized by a basin-wide change in the sedimentation rate mostly affecting the sediments dating to the interval of 2700-2200 cal year BP. Thus, the mid-point of "Phase 2" in Figure 8 should not be interpreted as the time of the dredging operation of the pond but rather, the mean age for the removed sediments. The red to orange colors in Figure $8 \mathrm{c}$ denote that maximum change in the depositional history of the pond affected sediments dating to the Achaemenid to Parthian period (sixth century BCE to first century $\mathrm{CE}$ ).

\subsection{3 | Phase 3: Abandonment}

According to the age-depth models (e.g., in PAL05 in Figure 6), after the enlargement phase of the lake and the active use of the Palace of Ardashir, the sedimentation rate increased again. The average accumulation rate for the whole basin increased from 18.82 year $/ \mathrm{cm}$ for the natural phase to 86.74 year/cm for the anthropogenic phase (Figure $8 \mathrm{~b})$. The sediment's nature also changed, with magnetic sediments dominating the upper part of cores PAL01 and PAL02. Even in those cores with mostly organic sediments, the remanent magnetic field values increase, showing the contribution of ferromagnetic sediments in mostly authigenic sediments of the pond.

These sediments are most probably the product of the site abandonment and consequent weathering and erosion of the architectural structures. This situation is ongoing. Thus, the abandonment phase was associated with gradual terrestrialization of the pond, mostly in its littoral zone facing the Palace.

\subsection{Summary of results}

The Ardashir spring and pond is a significant permanent water resource of the Firuzabad Plain (Barzi, 1997). Our data indicate that this ecosystem existed at least since the third millennium BCE ( $>4500$ cal year BP), long before the Sasanian occupation of the area.

At the time of the palace's construction, the pond was part of a larger wetland complex composed of the pond itself and a vast waterlogged area that most probably extended to the north and northeast. This latter part of the paleo-wetland was not permanently underwater. During higher water tables, possibly related to the higher discharge of the main spring and the smaller ones in its periphery, the area formed a shallow marsh or swamp environment. The runoff from the northwestern slopes contributed to the wetland water balance, especially during winter and early spring. Lower water tables transformed the shallower parts of the wetland into a waterlogged area, which could gradually be desiccated during the dry season and was colonized by terrestrial vegetation.

The unique physiography and hydrology of the pond basin enabled a planned reshaping of the landscape, leading to the integration of the pond into the palace's architecture. The sedimentary record of the pond -supported by the Bayesian age-depth models-confirms such a hydrological reorganization of the site and places this event at the beginning of the Sasanian period, corresponding to the construction of the Palace (Djamali et al., 2017; Huff, 1978).

The distribution and geometry of sedimentary units suggest that the wetland's sediments were heterogeneously removed to create a larger water body in front of the palace. The sharp decline in sedimentation rates suggests that the whole site became sufficiently isolated from the surrounding environment. The remains of the encompassing walls can be seen in the site's aerial photograph (Figure 2). The presence of rock circle structures nowadays buried under the surface (Figure 3a) further suggests that an anthropogenic structure enclosed the lake.

The Palace of Ardashir lost its prominent residency status after Shapur I built the city of Bishapur. Yet, the Palace was occupied until the collapse of Sasanian rule in the seventh century $C E$, based on coinage finds (Huff, 1999; Miri, 2009). Historical accounts report a bitter defense in this area during the Arab invasion (Hinds, 1984; Le Strange, 1905).

The abandonment of the palace is reflected in most of the sediment cores. After the cessation of pond management, the site's gradual degradation slightly increased the exogenous sediment input due to weathering and erosion of construction materials and re-entry of natural runoff into the site. Some of the deeper age inversions may indicate the pond terrestrialization and development of a deeply rooted woody vegetation on the pond's marginal zone, especially on the palace side (e.g., PALO2 in Figure 6).

The circular city next to the palace continued to flourish as an agricultural and trade center, until the 14th century CE, especially in the Buyids era (10th-11th century CE) (Le Strange \& Nicholson, 1921). The outlet canal from the pond has remained active in the irrigation of the arable land of the plain, up until today.

In summary, our study reveals three clear stages in the evolution of Ardashir Pond: (i) the natural state before the foundation of the palace in its direct vicinity, (ii) the intentional 
and planned modification of the pond and its integration as an architectural element into the palace complex during the Sasanian period, and (iii) the reclaimed semi-natural state after the abandonment of the palace. This hydro-sedimentary evolution is seen in the extensively dated sedimentary record and confirms the practice of reshaping the landscape, including complex water management in the Sasanian era.

\section{4 | DISCUSSION AND CONCLUSION}

\subsection{Landscape reshaping in Early Sasanian urban projects}

The idea of landscape reshaping for large-scale urban projects in ancient Persia is not unique to Sasanians. Archaeological evidence attests to such practices since the early third millennium BCE in this region. Historical accounts report such projects by Elamites, Achaemenians, and Arsacids (Parthians), before the Sasanians (Canepa, 2018). Landscape modification was also practiced in neighboring regions in the Sasanian period throughout four centuries (Daryaee, 2009; Huff, 2008; Mittertrainer, 2020).

What makes the Early Sasanian period unique is the optimized and extremely adaptive approach to reshaping any landscape into an institutional unit of the central government based on its limitations and resources (Daryaee, 2009). This becomes clear by comparing the diverse water management techniques at Ardashir Palace on the plain (Huff, 1999) with those of Qale Dokhtar, on the Tangab gorge (Huff, 1978), both built by Ardashir I. While the Palace of Ardashir on the plain is watered by a spring-fed pond and canals, at the fortified Palace of Qale Dokhtar, a deep well was dug into the gorge to provide water for the inhabitants through a rectangular basin (Huff, 2006). Hence, each example of the Sasanian institutional landscape is unique in its plan, while bearing the Sasanians' distinguishable mark (Canepa, 2018; Daryaee, 2009).

Although the idea of Sasanian's pre-imposed planning in reshaping their landscapes has been much debated among archaeologists and historians, solid evidence based on a case study such as the Ardashir Pond has never been provided. Therefore, the extent and effect of this practice could not be investigated beyond speculation. Here, we presented an interdisciplinary investigation of an element within the Sasanian landscape of Firuzabad, supporting a long-lasting hypothesis of landscape reshaping during the Early Sasanian period. ${ }^{7}$ We argue that such a time-consuming and rather extensive landscape reshaping was based on the concept of

${ }^{7}$ This study reports one aspect of our interdisciplinary project at Aix-Marseille University. The project aims to address the institutional landscape of Firuzabad by combining paleoenvironmental and archaeological studies, based on extensive fieldwork and analysis. Settlement history and spatial interaction of the settlements with their landscape, water management systems, and the evolution of land-use practices before and after the city's foundation are the main topics of this project. The results will be presented successively in a series of papers in the near future.
"Iranshahr," borated in a broader context.

\subsection{Ardashir Pond in a broader context}

Ardashir Pond has been chosen for this study because it is one of the first archaeologically known and historically documented cases of manipulating a water body and integrating it into monumental architecture in Late Antiquity, a practice that became a signature of Eastern architecture (Canepa, 2018, p. 104; Pope, 1965).

The intention of Sasanians in reshaping the landscape and manipulating water features into a desired shape is a demonstration of two key concepts of Sasanian ideology of Iranshahr, both introduced by Ardashir I: (i) the establishment of the divine ruler (Daryaee, 2009; Huff, 2014) and (ii) the religious implications of water in geometrical shapes (Boyce et al., 1989; Huff, 2014, p. 158). The concept of Iranshahr (MacKenzie, 1998) is present in all aspects of Sasanian life, such as art and architecture as well as the structure of society (Daryaee, 2009). The pond is fed by a spring, the latter being the most favorable form of the water body in Sasanian ideology (Canepa, 2018, p. 126).

This study focused on the micro-landscape of Ardashir Pond as an architectural element of the palace and an environmental factor in the evolution of its immediate landscape. The Palace of Ardashir was the first official seat of the founder of the Sasanian empire. It was an architectural innovation (Huff, 2014) and a template for future Sasanian and Islamic monumental structures. The prominent location of the pond may have had three main implications: (i) practical, (ii) ideological, and (iii) representative.

In practical terms, the pond was the source of freshwater for the palace complex. Its location in front of the main entrance had a cooling effect on the main hall, and irrigated the royal garden surrounding the palace. Furthermore, the pond and its spring were a manifestation of Anahid ${ }^{9}$ (Boyce et al., 1989), the goddess of water, which played an outstanding role in the Sasanian interpretation of the Zoroastrian religion (Daryaee, 2009). By integrating a human-modified spring into his first royal seat, Ardashir I manifested his official reading of the diverse religious practices of that time. He established a higher place for Anahid and accentuated his different religious understanding from the Arsacians, as well as numerous vassal kings of Iran in the third century CE (Daryaee, 2009, p. 71). This tradition was followed by all Sasanian rulers who followed.

The circular shape of the pond repeats the shape of the circular city of Ardashir Khurra. The pond reflects the well-constructed main entrance with its innovative "ayvan." It contributes to the pleasing view of the palace and impresses the visitor as an aesthetic component. In this regard, the pond is an indispensable element of the complex for an impressive representation of Sasanian power and

${ }^{8} \bar{E}$ rānšahr.

${ }^{9}$ Anāhīd/Ardwīsūr Anāhīd (she who possesses waters). 
harmony. Even in its current state of ruin, the extent of the pond's presentative function can be assumed, as it was also documented by Medieval Age historians (Afshar, 1961; Le Strange \& Nicholson, 1921) and early modern travelers (Flandin \& Coste, 1851).

\section{3 | Implications for future studies}

As a registered UNESCO site, the Sasanian landscape of the Fars region is a unique example of intentional and large-scale landscape manipulation of Late Antiquity. As the report mentions, "The archaeological landscape reflects the optimized utilization of natural topography." (UNESCO report available at https://whc.unesco.org/ en/list/1568/). Furthermore, the site presents a "highly efficient system of land-use" by exploiting local material and adapting it to the landscape's limitations.

Future studies will explore the extent of this practice in detail. The present study contributes to a better comprehension and conservation of this recently registered world heritage site. The results are crucial for both conservation purposes and academic discourse. Our study highlights the importance of the Ardashir Pond as a unique archive for environmental change in the vicinity of the Palace of Ardashir in the course of this institutional landscape change. The sediments of the pond have preserved invaluable environmental information, which was partly explored in this study. An ongoing paleoecological and geochemical investigation of the sediments has also yielded promising results (unpublished data) suggesting that a multi-proxy palaeoenvironmental study of the pond's sediments will add to our knowledge of the evolution of the local and regional landscape.

Indeed, ponds-like other wetland types-can reveal environmental information that cannot be provided by archaeological materials and textual references. Thus, they are of utmost heritage value, especially when located in archaeologically significant contexts (Bell \& Blais, 2020). Their environment and sediments need to be protected from disturbance, removal, and exploitation (Pond Conservation for Life in Freshwater Waters, 2010).

Our investigation serves as a model for future studies regarding integrating natural elements into the palatial constructs of the Classical period and Late Antiquity. The Ardashir Pond is an excellent case study for the interaction of natural and anthropogenic facets of a landscape. Investigating the intentional manipulation of water resources such as Ardashir Pond in the premodern era is particularly interesting as it may also provide in sights into forgotten sustainable ways of water management in the context of global change.

\section{ACKNOWLEDGMENTS}

We wish to thank the Iranian National Centre for Oceanography and Atmospheric Sciences and particularly its director Prof. Behrouz Abtahi for all their support from the beginning of this study. Morteza Djamali and Hamid Lahijani wish to thank the Iranian Vice-Presidency for Science and Technology and Iran's National Elites Foundation for their support of the scientific cooperation between INIOAS and Institut Méditerranéen de Biodiversité et d'Ecologie. Morteza Djamali is grateful to the staff members of the municipal library of Marseille (the Alcazar) Olivier Polère and Thierry Conti (Fonds rares et précieux) for their generous help and cooperation in providing access to Pascal-Xavier Coste's archive. We are indebted to two anonymous reviewers and the associated editor of the journal for their invaluable and constructive comments and corrections to our manuscript. Field investigations were supported by the "PALEO-PERSEPOLIS" project (2015-2019) funded by the Agence Nationale de la Recherche (ANR-14-CE35-0026-01). Radiocarbon datings were funded by the AQUA-IGNIS project supported by the AMIDEX Foundation (AixMarseille Université) and the LIA project entitled "HAOMA" supported by Centre National de la Recherche Scientifique (CNRS). Andrew Parnell's work was supported by a Science Foundation Ireland Career Development Award grant 17/CDA/4695 and an SFI centre grant 12/RC/2289_P2.

\section{AUTHOR CONTRIBUTIONS}

Alireza Askari-Chaverdi and Morteza Djamali conceived the project in 2016. Morteza Djamali, Emmanuel Gandouin, Elodie Brisset, Cyril Aubert, and Nicolas Faucherre participated in the field sampling and contributed to data interpretation. Emmanuel Gandouin and Cyril Aubert performed preliminary study of cores and helped with C-14 sample selections. Morteza Djamali and Andrew Parnell made the sediment description and age-depth models. Morteza Djamali and Elnaz Rashidian led the writing. Alireza Askari-Chaverdi and Elnaz Rashidian largely contributed to the analysis and integration of historical and archaeological knowledge. Abdolmajid Naderi-Beni and Hamid Lahijani supported the field operations and contributed to interpreting the data. François Demory performed and interpreted the IRM data. Nick Marriner contributed to data interpretation and improved the English of the manuscript.

\section{ORCID}

Morteza Djamali (D) http://orcid.org/0000-0001-7304-7326

Elodie Brisset (D) http://orcid.org/0000-0001-8706-0505

Abdolmajid Naderi-Beni (D) http://orcid.org/0000-0002-0825-1539

\section{REFERENCES}

Afshar, I. (1961). Masalek va Mamalek by Istakhri [translated to Persian]. Bongah-e Nashr va Tarjomeh.

Alonso-Zarza, A. M. (2003). Palaeoenvironmental significance of palustrine carbonates and calcretes in the geological record. Earth Science Reviews, 60, 261-298. https://doi.org/10.1016/ S0012-8252(02)00106-X

Ashjari, J., \& Raeisi, E. (2006). Lithological control on water chemistry in karst aquifers of the Zagros Range, Iran. Cave and Karst Sciences, 33, 111-118.

Barzi, A. (1997). Water resources and problems in Firuzabad Plain, Fars (Master Thesis). Islamic Azad University of Laristan, Laristan.

Bell, M. A., \& Blais, J. M. (2020). Paleolimnology in support of archaeology: A review of past investigations and a proposed framework for future study design. Journal of Paleolimnology, 65, 1-32. https://doi. org/10.1007/s10933-020-00156-8 
Boucharlat, R. (1979). Le monument rupestre de Qadamgah (Fars): Essai d'interprétation. Iranica Antiqua, 14, 153-166.

Boyce, M., Chaumont, M. L., \& Bier, C. (1989). ANĀHĪD. Encyclopedia Iranica, 1, 1003-1011.

Bronk Ramsey, C. (2009). Bayesian analysis of radiocarbon dates. Radiocarbon, 51, 337-360. https://doi.org/10.1017/S0033822200033865

Callieri, P. (2014). Architecture et représentations dans I'Iran sassanide (Cahier de Studia Iranica) (Vol. 50). Peeters.

Canepa, M. (2018). The Iranian expanse: Transforming royal identity through architecture, landscape, and the built environment, 550 BCE-642 CE. University of California Press.

Centore, P. (2013). Conversions between the Munsell and sRGB colour systems. https://www.munsellcolourscienceforpainters.com

Cereti, C. G. (2012). Kārnāmag i irdaxšēr ī Pābagān. Encyclopedia Iranica, 15, 585-588. https://www.iranicaonline.org/articles/karnamag-i-ardasir

Daryaee, T. (2009). Sasanian Persia. The rise and fall of an empire. I.B. Tauris.

Daryaee, T. (2010). Ardaxšir and the Sasanian's rise to power. ANABASIS, Studia Classica et Orientalia, 1, 236-255.

Demory, F., Uehara, M., Quesnel, Y., Rochette, P., Romey, C., Tachikawa, K., Garcia, M., Borschneck, D., Pignol, L., Bard, E., \& Andrieu-Ponel, V. (2019). A new high-resolution magnetic scanner for sedimentary sequences. Geochemistry, Geophysics, Geosystems, 20, 3186-3200. https://doi.org/10.1029/ 2019GC008343

Djamali, M., Askari-Chaverdi, A., Balatti, S., Guibal, F., \& Santelli, C. (2017). On the chronology and use of timber in the palaces and palace-like structures of the Sasanian Empire in "Persis" (SW Iran). Journal of Archaeological Sciences, Reports, 12, 134-141. https://doi.org/10. 1016/j.jasrep.2017.01.030

Djamali, M., Esu, D., Gliozzi, E., Okhravi, R., \& Soulié-Marsche, I. (2006). Palaeo-environment of a lacustrine-palustrine carbonate complex: Zarand Basin, Saveh, Central Iran. Palaeogeography, Palaeoclimatology, Palaeoecology, 237, 315-334. https://doi.org/10.1016/j.palaeo.2005. 12.001

Djamali, M., Gondet, S., Ashjari, J., Aubert, C., Brisset, E., Longerey, J., Marriner, N., Mashkour, M., Millet, N. F., Naderi-Beni, A., Pourkerman, M., Rashidian, E., Rigot, J.-B., Shidrang, S., Thiéry, A., \& Gandouin, E. (2018). Karstic-spring wetlands of the Persepolis Basin, SW Iran: Unique sediment archives of Holocene change and human impact. Canadian Journal of Earth Sciences, 55, 1158-1172. https:// doi.org/10.1139/cjes-2018-0065

Flandin, E. N., \& Coste, P.-X. (1851). Voyage en Perse (Tome 2). Gide et J. Baudry, Librairies Editeurs.

Freytet, P., \& Plaziat, J. C. (1982). Continental carbonate sedimentation and pedogenesis. Late Cretaceous and Early Tertiary of Southern France. Contribution to sedimentology (Vol. 12). Springer-Verlag.

Haslett, J., \& Parnell, A. (2008). A simple monotone process with application to radiocarbon-dated depth chronologies. Journal of the Royal Statistical Society: Series C (Applied Statistics), 57, 399-418. https://doi.org/10.1111/j.1467-9876.2008.00623.x

Hinds, M. (1984). The first Arab conquests in Fars. Iran, 22, 39-54. https://doi.org/10.2307/4299735

Huff, D. (1972). Der Takht-i Nishin in Firuzabad. Archäologischer Anzeiger, 4, 517-544.

Huff, D. (1978). Ausgrabungen auf Qal'a-ye Dukhtar bei Firuzabad 1976. AMI, 11, 117-147.

Huff, D. (1999). Firuzabad. Encyclopedia Iranica, 9, 633-636.

Huff, D. (2006). Qal'a-ye Dokhtar. Encyclopedia Iranica. http://www. iranicaonline.org/articles/qala-ye-doktar

Huff, D. (2008). Formation and ideology of the Sasanian State in the context of archaeological evidence. In: V. S. Curtis \& S. Stewart (Eds.), The Sasanian Era. I.B. Tauris (pp. 31-59).

Huff, D. (2014). Das Plansystem von Ardašǐr-xwarrah: Agrarkolonisatorisches Großprojekt und gebautes Staatsmodell eines von Gott gegebenen Königtums. Raumkonzeptionen in antiken Religionen: Beiträge des internationalen Symposiums in Göttingen, 28-29. Juni 2012 (pp. 153-210). Harrassowitz.

Hugi, H. (1977). Ghala-Dokhtar-Atechkade: monuments sasanides près de Firouzabad, Iran. Rapport préliminaire des projets de consolidation et restauration. Organisation Nationale pour la Conservation des Monuments Historiques.

Le Strange, G. (1905). The lands of the eastern caliphate: Mesopotamia, Persia, and Central Asia from the Moslem conquest to the time of Timur. Cambridge University Press.

Le Strange, G., \& Nicholson, R. (1921). The Fārs-Nāma of Ibnu I-Balkhi. Cambridge University Press.

Lev, L., Boaretto, E., Heller, J., Marco, S., \& Stein, M. (2007). The feasibility of using Melanopsis shells as radiocarbon chronometer, Lake Kinneret, Israel. Radiocarbon, 49, 1003-1015. https://doi.org/10. 1017/S0033822200042867

MacKenzie, D. N. (1998). ĒRĀN, ĒRĀNŠAHR. Encyclopedia Iranica, 8, 534.

Marriner, N., \& Morhange, C. (2006). Geoarchaeological evidence for dredging in Tyre's ancient harbour, Levant. Quaternary Research, 65, 164-171. https://doi.org/10.1016/j.yqres.2005.07.004

Marriner, N., \& Morhange, C. (2007). Geoscience of ancient Mediterranean harbours. Earth-Science Reviews, 80, 137-194. https://doi.org/10.1016/j.earscirev.2006.10.003

Mashkour, M. J. (1950). Karnamak i Ardashir i Papakan: Records of Ardashir Babakan, the founder of the Sasanian dynasty in Iran [in Persian and Pahlavi]. Anjoman-e Athar-e Melli.

Miri, N. (2009). Historical geography of Fars during the Sasanian Period. e-Sasanika, 6, 1-65.

Mittertrainer, A. (2020). Sinnbilder politischer Autorität? Frühsasanidische Städtebilder im Südwesten Irans. Readbox Publishing.

Mousavi, A., \& Daryaee, T. (2012). The Sasanian Empire: An Archaeological survey. In D. A. Potts (Ed.), A companion to the archaeology of the ancient Near East. Wiley-Blackwell.

Munsell Color Company. (2000). Munsell soil color charts.

Novikmec, M., Hamerlík, L., Kočický, D., Hrivnák, R., Kochjarová, J., Otahelová, H., Palove-Balang, P., \& Svitok, M. (2016). Ponds and their catchments: Size relationships and influence of land use across multiple spatial scales. Hydrobiologia, 774, 155-166. https://doi.org/ 10.1007/s10750-015-2514-8

Parnell, A. C., Haslett, J., Allen, J. R. M., Buck, C. E., \& Huntley, B. (2008). A flexible approach to assessing synchroneity of past events using Bayesian reconstructions of sedimentation history. Quaternary Science Reviews, 27, 1872-1885. https://doi.org/10.1016/j.quascirev.2008. 07.009

Pond Conservation for Life in Freshwater Waters. (2010). Ponds of historical interest. Freshwater Habitats Trust. https://freshwaterhabitats.org.uk/ wp-content/uploads/2013/09/FAQ-Ponds-of-Historic-Interest.pdf

Pope, A. U. (1965). Persian architecture. George Braziller.

Reimer, P., Austin, W., Bard, E., Bayliss, A., Blackwell, P., Bronk Ramsey, C., Butzin, M., Cheng, H., Edwards, R., Friedrich, M., Grootes, P., Guilderson, T., Hajdas, I., Heaton, T., Hogg, A., Hughen, K., Kromer, B., Manning, S., Muscheler, R., ... Talamo, S. (2020). The IntCal20 Northern Hemisphere radiocarbon age calibration curve (0-55 cal kBP). Radiocarbon, 62, 725-757. https://doi.org/10.1017/ RDC.2020.41

R Studio Team. (2015). RStudio: Integrated Development for R. RStudio, Inc. http://www.rstudio.com/

Sedaghat, M. E., Khademi, A., \& Nimroozi, A. (2000). 1:100,000 Geological map of Firoozabad. Geological Survey and Mineral Exploration of Iran.

Sharifi, A., Murphy, L. N., Pourmand, A., Clement, A. C., Canuel, E. A., Naderi Beni, A., Lahijani, H. A. K., Delanghe, D., \& Ahmady-Birgani, H. (2018). Early-Holocene greening of the Afro-Asian dust belt changed sources of mineral dust in West Asia. Earth and Planetary Science Letters, 481, 30-40. https://doi.org/10.1016/j.epsl.2017.10.001 
Sharifi, A., Pourmand, A., Canel, E. A., Ferer-Tyler, E., Peterson, L. C., Aichner, B., Feakins, S. J., Daryaee, T., Djamali, M., Naderi Beni, A., Lahijani, H. A. K., \& Swart, P. K. (2015). Abrupt climate variability since the last deglaciation based on a highresolution, multi-proxy peat record from NW Iran: The hand that rocked the Cradle of Civilization? Quaternary Science Reviews, 123, 215-230. https://doi.org/10.1016/j.quascirev.2015.07.006

Simpson, S. (2017). Sasanian cities: Archaeological perspectives on the urban economy and built environment of an empire. In E. Sauer (Ed.), Sasanian Persia: Between Rome and the steppes of Eurasia (pp. 21-50). Edinburgh University Press.

Wiesehöfer, J. (2001). Ancient Persia: From 550 BC to 650 AD. I.B. Tauris.
How to cite this article: Djamali, M., Rashidian, E., AskariChaverdi, A., Aubert, C., Brisset, E., Demory, F., Faucherre, N., Gandouin, E., Lahijani, H., Marriner, N., Naderi-Beni, A., \& Parnell, A. (2021). Early Sasanian landscape modification: New geoarchaeological evidence from the Ardashir Pond in southwest Iran (Palace of Ardashir, third century CE). Geoarchaeology, 36, 925-942. https://doi.org/10.1002/gea.21880 